\title{
18. EKOKRITIČKO ČITANJE ROMANA PRONALAZAK ATHANATIKA VLADANA DESNICE
}

\section{Goran Đurđević}

UDK: 821.163.42-311.9Desnica, V.:612.013

Prethodno priopćenje

Sažetak: Autor iz ekokritičke niše pristupa čitanju kratkog nedovršenog romana Vladana Desnice Pronalazak Athanatika. Rad čine tri tematske cjeline: ekokritički pristup tematskom ciklusu život - smrt - besmrtnost u komparaciji i povezivanju s djelom Homo Deus Yuvala Noaha Hararija, zatim ekokritička analiza kiše kroz prizmu ideja Susan Farrell te analiza Pronalaska Athanatika u kontekstu distopijskih ekoloških/okolišnih romana u suvremenoj hrvatskoj književnosti Planet Friedman Josipa Mlakića i Mjesečev meridijan Ede Popovića, uz usporedbu s ekokritičkim čitanjima Louise Squire. Autor zaključuje kako je Desnica svojim djelom Pronalazak Athanatika - koje žanrovski pozicionira kao spekulativnu fikciju - prethodnik koji korelira s aktualnim znanstvenim promišljanjima (Harari) i književnim djelima (Mlakić, Popović), upozoravajući kako ekologija i ekološki čimbenici - besmrtnost i porast stanovnika, nedostatak hrane te u konačnici uništavanje planeta - mogu imati razorne učinke na društvene promjene, raspodjelu moći i oblikovanje budućnosti. ${ }^{1}$

Ključne riječi: ekokritika, Pronalazak Athanatika, Vladan Desnica, besmrtnost, Yuval Noah Harari, Josip Mlakić, Edo Popović, kulturalni studiji

\section{UVOD}

edamdesete godine dvadesetog stoljeća otvaraju nove prozore i poglede na čovjekov svijet i čovječanstvo. Društveno-politički naslonjene su na događaje iz 1968. i pokušaje promjena studentskim demonstracijama, rastuću dekolonizaciju i oslobođenje zemalja Trećeg svijeta, zatim na otpor prema američkoj intervenciji u Vijetnamu i strahovima od mogućeg nuklearnog sukoba hladnoratovskih suparnika, ali i naftnu (energetsku) krizu. Takvo vrijeme, praćeno tehnološkim razvitkom, utemeljenim u napretku prirodnih i teh-

$1 \quad$ Zahvaljujem Dariji Đurđević i prof. dr. sc. Jožici Čeh Stergar na pomoći oko nabave literature, kolegi Vinku Tadiću na mudrim savjetima, posebno oko povijesne literature, te doc. dr. sc. Suzani Marjanić i doc. dr. sc. Mirandi LevanatPeričić na iznimnoj pomoći pri oblikovanju ideja, kao i anonimnim recenzentima i urednicima na konstruktivnim, kreativnim i dobronamjernim savjetima i strpljenju. 
ničkih znanosti, pojavom brojnih izuma koji olakšavaju svakodnevni život te ubrzanim nastankom potrošačkog društva, otvara nove mogućnosti u kreiranju svijeta, prateći tadašnje izazove i probleme, što omogućuje pojavu i začetke ekoloških (zelenih), feminističkih (rodnih i ženskih), mirotvornih (antiratnih) i drugih pokreta. Oni promatraju svakodnevicu drugačijim očima i otvaraju prostor novim temama, čineći uvod u postmodernu. U sklopu postmoderne otvoren je put, među ostalima, za kulturne studije, popularnu kulturu, ekokritiku/ekokriticizam, ${ }^{2}$ ekofeminizam, lingvistički obrat, analizu diskursa i mnoge druge subdiscipline, istraživačke pravce i teorijsko-metodološke inovacije. ${ }^{3}$

Ekokritika je kao jedan od novijih pristupa suvremenosti otvorila drugačije perspektive analiziranja kulture - ponajviše književnosti i vizualnih umjetnosti - u kontekstu doticaja s okolišem. Pojam ekokritike osmislio je William Rueckert u svom članku „Literature and Ecology: An Experiment in Ecocriticism“iz 1978. godine. Definirao ga je kao povezivanje ekoloških koncepata i književnosti. ${ }^{4}$ Prvu ideju povezivanja prirode i književnosti, prema mišljenju Petera Berryja i Domagoja Brozovića, donosi Karl Kroeber u radu „'Home at Grasmere’: Ecological Holiness“, objavljenom još 1974. godine. ${ }^{5}$ Cheryll Glotfelty, urednica zbornika The Ecocriticism Reader. Landmarks in Literary Ecology, donosi sljedeću definiciju:

Ekokritika je studij veze između književnosti i fizičkog okoliša. Baš kao što feministička kritika istražuje jezik i književnost iz rodno osviještene perspektive i baš kao što marksistička kritika donosi svijest o načinima proizvodnje te o ekonomskim klasama u svoja čitanja tekstova, ekokritika zauzima geocentrični pristup književnim studijima... Ekokritika dijeli fundamentalnu premisu da je ljudska kultura povezana s fizičkim svijetom, da djeluje na njega i da se djeluje na nju. Ekokritika uzima kao svoju temu međupovezanost prirode i kulture, posebice kulturalne artefakte jezika i književnosti...6

Subdisciplina se razvija od kraja osamdesetih, a posebno u devedesetima i dvijetisućitima, kada su se osnivale strukovne udruge $\left(\mathrm{ASLE}^{7}\right.$ i EASLCE ${ }^{8}$ ), pokretali časopisi i zbornici. Američka je ekokritika usmjerena na autore 19. stoljeća i njihovo pisanje o prirodi (interpretacije divljine, krajolika, motiva i tema), što bi značilo usmjeravanje $\mathrm{k}$ povratku prirodi

2 U radu se dosljedno koristim terminom ekokritika, koji je u svojim radovima, prvima koji su se doticali ove tematike, rabila Suzana Marjanić, a ne ekokriticizam, kako je predložio Domagoj Brozović. Usp. Suzana MarJanić, „Književni svjetovi s etnološkom, ekološkom i animalističkom nišom", Narodna umjetnost, 43/2006., br. 2, 163-186; IstA, „Zoosfera Tita Andronika: ljudska, previše ljudska bestijalnost“, Tré́a, 10/2008., br. 2, 59-82; Domagoj Brozović, „Čitati zeleno. Ekokriticizam - neprepoznata mogućnost suvremene hrvatske znanosti o književnosti“, Književna smotra, 44/2012., br. 164-165, 29-35.

3 U nepreglednom broju naslova o promjenama u različitim aspektima društvene zbilje sedamdesetih godina usp. Thomas Borstelmann, The 1970s. A New Global History from Civil Rights to Economic Inequality, Princeton 2015. i Niall Ferguson i dr. (ur.), The Shock of the Global. The 1970s in Perspective, Harvard 2011.

4 William Rueckert, „Literature and Ecology: An Experiment in Ecocriticism“, Ecocriticism Reader. Landmarks in Literary Ecology (ur. Cheryll Glotfelty i Harold Fromm), Athens, Georgia 1996., 107.

5 Peter Berry, Beginning Theory. An Introduction to Literary and Cultural Theory, Manchester - New York 2009., 240; D. Brozović, „Čitati zeleno“, 29. Usp. i Karl Kroeber, "'Home at Grasmere’: Ecological Holiness“, Publications of the Modern Language Association of America, 89/1974., br. 1, 132-141.

6 Citirano prema D. Brozović, „Čitati zeleno“, 30. Usp. i Cheryll Glotfelty, „Introduction: Literary Studies in an Age of Environmental Crisis", Ecocriticism Reader. Landmarks in Literary Ecology (ur. Cheryll Glotfelty i Harold Fromm), Athens, Georgia 1996., XVIII.

7 Za samu organizaciju Association for the Study of Literature and Environment v. službenu stranicu https://www.asle. org.

8 Podaci o strukovnoj udruzi European Association for Study of Literature Culture and Environment dostupni su na: https://www.easlce.eu. 
te slavljenju prirode kao takve, dok je britanska više orijentirana prema odnosu kulture i prirode kroz prizmu antropocentričnih prijetnji prirodi (odnosno okolišu). Jedan od izazova, prema mišljenju Domagoja Brozovića, zasigurno je nedostatak čvršće metodološke i terminološke literature, ${ }^{9}$ praksi i obrazaca. Pri tome je jedno od središnjih pitanja: tko ili što je u središtu ekokritičkog čitanja književnih djela: čovjek ili priroda? Ekokritičari tumače prirodu i kulturu kao fenomene, a ne kao jezične, umjetne konstrukte. ${ }^{10}$

Odnos prirode i kulture uobličen u ekokritičkim čitanjima književnih djela poticajan je za analizu romana Pronalazak Athanatika autora Vladana Desnice. Inicijalna piščeva ideja o lijeku za besmrtnost i promjenama koje ima u svijetu dobra je podloga za iščitavanje međusobnih odnosa kulture i prirode te promatranje prirode kao subjekta, a ne samo kao marginaliziranog objekta.

Ovaj rad zamišljen je kao kolaž od triju tematskih cjelina: ekokritički pristup životu smrti - besmrtnosti u komparaciji i povezivanju Desničina nedovršenog romana s djelom Homo Deus; zatim ekokritička analiza kiše kroz prizmu ideja Susan Farrell; analiza Pronalaska Athanatika u kontekstu distopijskih ekoloških/okolišnih romana u suvremenoj hrvatskoj književnosti Planet Friedman Josipa Mlakića i Mjesečev meridijan Ede Popovića, uz usporedbu s ekokritičkim čitanjima koncepta antropocena autorice Louise Squire.

\section{2. こ̌LIVOT - SMRT - BESMRTNOST: EKOKRITIČKI PRISTUP PRONALASKU ATHANATIKA}

Još su u prapovijesti ljudi stvorili binarni sustav sastavljen od života i smrti. Dok se prva inačica tog sustava mogla jasno raspoznavati čovjekovim rođenjem i samim životom, ona druga - smrt - ostala je zagonetna, mistična i izazovna. Iz tih se razloga u brojnim mitovima, religijama, likovnim i književnim djelima pojavljuje priča o besmrtnosti i potraga za njom kao svojevrsnom pobjedom nad smrću. ${ }^{11} \mathrm{U}$ pojedinim se mitologijama besmrtnost povezuje uz određene biljke, prirodne osobitosti (planine, more, nepoznati krajevi) ili život junaka i bogova. ${ }^{12} S$ druge strane, većina monoteističkih religija smrt doživljava kao nastavak života na drugom svijetu, ovisno o okolnostima i zemaljskom životu osobe. ${ }^{13} \mathrm{U}$ suvre-

$9 \quad$ U posljednje su vrijeme napravljeni značajni pomaci na tom polju, što se može vidjeti u radovima Dereka Gladwina s vrlo opsežnom bibliografijom i Simona C. Estoka. Usp. Derek Gladwin, „Ecocriticism“, Oxford Bibliographies (http://www.oxfordbibliographies.com/view/document/obo-9780190221911/obo-9780190221911-0014.xml); Simon C. Еsток, „Teorija s ruba: životinje, ekokritika, Shakespeare“, Kazalište, 11/2008., br. 35-36, 84-97.

10 Usp. D. Brozović, „Čitati zeleno“, 29-35.

11 Usp. Jacques Choron, „Death and Immortality“, Dictionary of the History of Ideas (ur. Philip P. Wiener), sv. 1, New York 1974., 635-646 (https://web.archive.org/web/20070311081839/http://etext.lib.virginia.edu/cgi-local/DHI/dhi. cgi?id=dv1-76).

12 Primjerice, Ep o Gilgamešu ili Putovanje na zapad pokazuju predodžbe potrage za besmrtnošću u sumerskoj, odnosno kineskoj mitologiji. Problem fenomena besmrtnosti u grčkoj mitologiji izložen je u mitu o Sizifu i njegovu zarobljavanju boga Thanatosa, čime je prestalo umiranje ljudi sve dok Thanatos nije oslobođen. Usp. Reginald CAMPBELL Thompson, The Epic of Gilgamesh: Complete Academic Translation. Translated from cuneiform tablets in the British Museum literally into English hexameters, London 2007.; Wu Cheng'en, A journey to the West, Beijing 1955.; „Sisyphus", Encyclopaedia Britannica (https://www.britannica.com/topic/Sisyphus).

13 U kršćanstvu se ovo manifestira postojanjem zagrobnog života u vidu raja, čistilišta (koje priznaju samo katolici) i pakla, dok je u islamu slična koncepcija s džennetom (raj) i džehennemom (pakao), a u judaizmu postoje shamayin 
menom svijetu 21. stoljeća aktualizirana je priča o besmrtnosti. Danas se besmrtnost ne doživljava pronalaskom određenog cvijeta ili lista pojedine biljke, jedenjem pojedinih namirnica (voća ili povrća), niti odlaskom u planine ili nepoznate krajeve, kakve su predodžbe bile u predmodernom svijetu, već pokušajima produljivanja ljudskog života korištenjem različitim tehnološkim mogućnostima, uključujući povezivanja s umjetnom inteligencijom, izumima, robotima i sličnim novinama.

Drugi binarni par koji proizlazi iz prvoga, odnosno čovjekova nastojanja za besmrtnošću, temeljno je pitanje ekokritike, sazdano u (su)odnosu između kulture i prirode. Njihovu dihotomiju najbolje definira William Howarth, atribuirajući ekokritičara/ekokritičarku kao „osobu koja analizira prednosti i nedostatke zapisa koji prikazuju učinke kulture na prirodu s namjerom slavljenja prirode, kritiziranja njezina iskorištavanja i ispravljanja štete učinjene kroz političku aktivnost". ${ }^{14}$

Književnik Vladan Desnica u svojim se raznim djelima doticao pitanja smrti i besmrtnosti, odabirujući ih kao svoju veliku temu, a najizraženije u nedovršenom romanu Pronalazak Athanatika. Ovaj kratak roman strukturiran je kao dijalog između pripovjedača i Krezubog, pripovjedačeva poznanika koji tumači svoju novu ideju, točnije, fabulu nenapisanog romana. Radnja je smještena u nedefiniranu budućnost (autor se koristi terminom

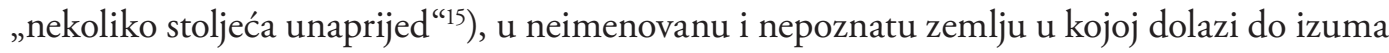
lijeka (injekcije) protiv smrti. Važno je naglasiti Desničinu terminološku odrednicu, kako uočava Krešimir Nemec, jer se pisac izričito koristi sljedećim terminima: lijek, hormon ili faktor Iks umjesto eliksir za izum athanatika (čiji i sâm naziv ukazuje o čemu je riječ: $a$ thanatos - protiv smrti) te vječita regeneracija ili beskonačno trajanje umjesto besmrtnost. ${ }^{16}$ Ovime se dodatno naglašava znanstvenost samog lijeka - uostalom, i izrijekom se navodi da je lijek produkt znanstvenih istraživanja - čime Desnica stavlja otklon od tradicionalnih pristupa besmrtnosti i potragama za eliksirima.

Daljnja radnja upućuje na društvene i ekonomske posljedice. U samom je početku izum doveo do neviđene euforije, radosti i slavlja, što se uskoro počelo mijenjati uvođenjem državne kontrole. Time se pokazalo da svaki život nije jednako vrijedan. Besmrtnost je realizirana posebnom ustanovom Izuzeća od smrti, koja je stvorila različite društvene skupine (klase) za dobivanje athanatika. Struktura je piramidalna i hijerarhijska, duboko povezana $s$ trenutačnom pozicijom moći, od predsjednika i premijera pa naniže. Ovakav je princip u romanu opravdan uobičajenim okolišnim problemom: nedostatkom dovoljne količine hrane. Uvedene mjere dovode do rasta nasilja, krađa, prevara, ubojstava, pobuna i revolucija. Rezultat je toga nastanak totalitarne države diktatora Maman-Mamona, koji kontrolira život i smrt svojih građana. Ubrzo su slijedila ubojstva, sukobi i ponovno korištenje plinskim komorama te diferencijacija ljudi na dvije veće skupine: smrtne i besmrtne. Iako je lijek usa-

(raj) i gehenna (pakao). Slični su koncepti i u istočnjačkim religijama poput budizma i hinduizma s, primjerice, raznim inačicama pakla, od kojih je najpoznatija naraka. Detaljnije o zagrobnom životu v. „Zagrobni život“, Hrvatska enciklopedija (http://www.enciklopedija.hr/natuknica.aspx?id=66705).

14 William Howarth, „Some Principles of Ecocriticism“, Ecocriticism Reader. Landmarks in Literary Ecology (ur. Cheryll Glotfelty i Harold Fromm), Athens, Georgia 1996., 69. Usp. i Tjaša TrČEK, Ekokritika - upodobitve narave v izbranih mladinskih delih, diplomski rad, Univerza v Ljubljani, Pedagoška fakulteta, 2016., 3.

15 Vladan Desnica, Pronalazak Athanatika, Zagreb 2006., 8.

16 Krešimir Nemec, „Pronalazak Athanatika - između utopije i distopije“, u: V. Desnica, Pronalazak Athanatika, 87. 
vršen na dva podtipa - A (koji je djelovao na sve vrste smrti, uključujući i onu nasilnu) i B (koji je djelovao samo u slučaju prirodne smrti) - nije se poboljšalo stanje jer su nedostatak hrane i posljedice lijeka (poremećaji) uvjetovali daljnje probleme. Završetak je rezultirao svjesnim uništavanjem lijeka, odnosno ljudskim odabirom smrtnosti umjesto besmrtnosti.

Aktualnost ove teme u počecima 21. stoljeća osnažuje pojava svjetskog bestselera poznatog izraelskog povjesničara Yuvala Noaha Hararija i njegova djela Homo Deus s vrlo znakovitim podnaslovom Kratka povijest sutrašnjice. Radi se o svojevrsnom nastavku njegove prethodne uspješnice Sapiens s podnaslovom Kratka povijest čovječanstva. U Sapiensu je Harari prikazom četiriju revolucija - kognitivne, agrarne, unifikacijske i znanstvene - objasnio kako je u prošlosti čovjek dosegao svoju današnju razinu, dok je u Homo Deusu ušao u problematiku budućnosti. ${ }^{17} \mathrm{U}$ uvodnom dijelu Harari donosi kratak prikaz povijesti kroz vizuru ljudske pobjede nad ratom (navodi da je veća šansa samoubojstvo nego ubojstvo u ratu), gladi (više je pretilih nego gladnih u svijetu) i bolestima (većina zaraznih, epidemijskih bolesti iskorijenjena je). Taj bi dio knjige, kako prikazuje Tizian Raspor, karakterizirao optimističan ton. ${ }^{18}$ Prvo je poglavlje zapravo Hararijevo objašnjenje ljudske prošlosti od početaka Homo sapiensa do danas, najmoćnijeg bića na planetu. Sukladno s naznačenim u Sapiensu, autor to objašnjava stvaranjem zajedničke kolektivne mašte, koja prelazi u mitove, omogućujući stvaranje povezane zajednice sastavljene od međusobno nepoznatih osoba. Takva je imaginacija omogućila stvaranje nacija, novca, religija, ljudskih prava, zakona i sličnih. Među ostalim pojmovima izdvaja pojam algoritam kao svojevrstan izvor zaključaka i donošenja odluka (umjesto korištenja intuicijom). U drugom poglavlju odlazi korak dalje, pokazujući nepomirenu razliku između moći i smisla te navodeći kako je izborom moći pojedinac sve bliži statusu božanstva (u tradicionalnim religijama) jer uspijeva kontrolirati i koordinirati različite procese. U posljednjem poglavlju donosi ideju dataizma (religija podataka) kao nove „religije“ utemeljene na moći i važnosti informacija te projekciju budućnosti u skladu s novim tehnološkim dostignućima, navodeći koje će to posljedice izazvati na društvena kretanja, uz mogući daljnji porast društvenih nejednakosti. ${ }^{19}$

Najvažnije potpoglavlje za ovu temu naslovljeno je „Posljednji dani smrti“. Harari ocrtava svoju tezu o besmrtnosti pričom o svetosti ljudskog života, koja se uočava u brojnim zakonodavnim i legislativnim aktima, kao i svakodnevnom životu, no napominje kako religije (kršćanstvo, hinduizam, judaizam) imaju drugačiji stav o smrti jer bez nje cijeli religijski koncept tih zajednica - koji uključuje raj, pakao i reinkarnaciju - postaje nemoguć. Suvremen čovjek, prema Harariju, umire zbog tehničkih problema - srce prestane kucati, središnja se arterija začepi ili se stanice raka prošire tijelom zato što srce ne dobiva zraka ili zbog genetske mutacije stanica. Njegova je teza o smrti najbolje složena u sljedećoj rečenici: „Ako je tradicionalno smrt bila specijalnost svećenika i teologa, danas su stvar preuzeli inženjeri. “' ${ }^{20}$ Smatra da je uvijek u pozadini tehnički problem, čak i pri vremenskim nepo-

17 Yuval Noah Harari, Sapiens. Kratka povijest čovječanstva, Zagreb 2015. Usp. i Goran ĐurĐević, „Yuval Noah Harari, Sapiens: kratka povijest čovječanstva, Fokus, Zagreb 2015, 479 str.“, Historijski zbornik, 68/2015., br. 1, $203-205$.

18 Tizian Raspor, „Yuval Noah Harari, Homo Deus. Kratka povijest sutrašnjice, prevela s engleskog Marija Perišić, Fokus komunikacije, Zagreb 2017, 461 str.", Historiografija.hr (http://www.historiografija.hr/?p=5663).

19 Yuval Noah Harari, Homo Deus. Kratka povijest sutrašnjice, Zagreb 2017. Usp. i Goran ĐurĐević, „Yuval Noah Harari, Homo Deus: kratka povijest sutrašnjice“, Ekonomska i ekohistorija, 13/2017., 177-178.

20 Y. N. Harari, Homo Deus, 26. 
godama, automobilskim nesrećama i sličnim nedaćama koje izazivaju smrt. Argumentira kako je internetska tražilica i jedna od najmoćnijih kompanija, Google, investirala mnogo sredstava u istraživanja i borbu protiv smrti, angažirajući dvojicu istaknutih znanstvenika i „promicatelja“ besmrtnosti - Rayja Kurzweila i Billa Marisa. Pritom Google nije jedina kompanija iz Silicijske doline koja investira u takva istraživanja. Besmrtnost će generirati različite društvene promjene u odabiru zanimanja, tijeku karijera, brakovima i strukturi obitelji, roditeljstvu. Harari završava poglavlje upozorenjima što bi se moglo dogoditi kad jednom znanost stvori uvjete za besmrtnost. Procjenjuje da će doći do sukoba, ratova i međusobnih borbi za besmrtnost, što će baciti sjenu na dosadašnje sukobe, u kojima će se strah od smrti zamijeniti ratovima, odnosno borbama za besmrtnost. ${ }^{21}$

Uspoređujući ovu dvojicu autora, Desnicu i Hararija, uočavamo da, neovisno o vremenskoj razlici u stvaranju svojih djela, pišu o istoj stvari iz sličnog kuta gledanja, ali s različitim rezultatima. Obojica pišu o besmrtnosti kao fenomenu budućnosti koji se temelji na znanosti i tehnologiji, pri čemu su ovdje stvorene prve razlike: Desnica izvor besmrtnosti vidi u lijeku, a za Hararija je besmrtnost napredak tehnologije (operacija zamjene organa razvojem robotike i zdravstveno-tehničkih uradaka). Princip lijeka za besmrtnost upućuje na povezivanje tradicionalnih poimanja dosezanja besmrtnosti (ljekovite trave ili određena hrana) s dosezima tadašnjeg doba (izum lijeka). Drugim riječima, Desnica pristupa problemu besmrtnosti i smrtnosti kao svojevrsnim bolestima te zamišlja kakve bi događaje i posljedice donio preventivan izumljen lijek za izostanak smrtnosti, odnosno sprečavanje umiranja. Hararijev je pristup sličan inženjerima suvremenog doba. On promatra ljudsko tijelo kao mehanizam s dijelovima određenog roka trajanja, koji se potom mijenjaju, čineći taj mehanizam manje-više trajnim. Desnica je vrlo zanimljivo povezao tradiciju (jedinstven pripravak koji naziva lijekom) i znanstveni pristup (sustavna istraživanja, izum) u pristupu besmrtnosti. Time je postao mostom između tradicije i najnovijih pristupa poput Hararijeva. U samom Desničinu Pronalasku Athanatika vidljiv je kontrast između lijeka/izuma, koji je uvijek produkt tehnološko-znanstvenog rada i time je već u samoj ideji (a i realizaciji) udaljen od tradicionalnih traženja lijeka za besmrtnost unutar prirode (odabirom određene biljke, putovanjem u udaljene, egzotične i nepoznate krajeve). Naveden odmak, bez obzira na to što je djelomično naslonjen na tradiciju (jer je riječ o pripravku), pokazuje koliko je čovjek planirajući i realizirajući athanatik napustio prirodu kao cjelinu u kojoj živi i djeluje i pretvorio se u hegemona.

Zajedničko je obojici to što smrtnost promatraju kao znanstveno-tehnički problem koji se može riješiti razvojem znanosti i tehnologije. Ovakav pristup promatranja smrti kao bolesti, odnosno tehničkog nedostatka i naslućivanje rješenja u tom pravcu upućuje na isključivanje čovjeka iz prirode (čiji je životni ciklus omeđen rođenjem, životom i smrću) kao nadređenog, odnosno gospodara koji kreira rješenje za produžetak života i izostanak smrtnosti. Druga živa bića ne mogu dobiti mogućnost besmrtnosti, čime se čovjek dodatno izdvojio i narušio odnose s prirodom, pokazujući dominaciju te stvarajući antagonizam između čovjeka i ostalih (pod tim podrazumijevam sva živa i neživa bića te prirodu). Očekivanja, koja su ljudi imali vrhuncem kulturnih i znanstvenih dostignuća te besmrtnošću, 
pretvorila su se u neočekivane posljedice otuđenja od prirode (a time i čovjeka), što je rezultiralo narušenim odnosima prema prirodi (kao i društvu, u vidu stvaranja totalitarnih režima).

Druga razlika koju iščitavamo jest u samoj besmrtnosti kao pojmu. U Desnice su prilikom izuma dvaju tipova athanatika (A i B) obuhvaćeni različiti tipovi smrti - prirodna i nasilna (odnosno neprirodna). Harari, pak, uzima zadršku prema neprirodnoj smrti, smatrajući da će dio ljudi umirati u nesrećama i ratnim sukobima pa se koristi terminom nesmrtni umjesto besmrtni.

Treći su dio usporedbe posljedice. Besmrtnost za Desnicu u ovom romanu ima pesimističan karakter jer se gubi jednakost u smrtnosti, što dovodi do stvaranja velikih socijalnih razlika u strukturi moći, da bi se u konačnici pojavili totalitarni sustavi koji prelaze $s$ kontrole života na sveobuhvatnu kontrolu života i smrti. Time se briše bilo kakva nada za ravnopravnost (jednakost u smrti i interpretacije zemaljskog života u zagrobnom svijetu pružale su utjehu i nadu brojnim religioznim stanovnicima). Međutim, završetkom djela Desnica otvara mogućnost pozitivnog kraja, neovisno o obnovi smrtnosti ljudi. U Hararija besmrtnost je (jedan od fenomena budućnosti) također obilježena pesimističnim tonom jer je ne smatra konačnim ciljem, već sredstvom stvaranja Homo Deusa od sadašnjeg Homo sapiensa. Besmrtnost se uklapa u cjelinu kao prvi dio niza: besmrtnost, sreća, božanstvenost. U zanimljivoj rečenici Harari pokazuje što bi mogla biti besmrtnost (i za koga): „Ako su Kurzweil i de Grey u pravu, možda već neki besmrtnici hodaju pored vas na ulici, posebno ako hodate Wall Streetom ili Petom avenijom. “22 Time naglašava društveno raslojavanje glede besmrtnosti jer će očito oni s najviše novca moći osigurati taj privilegij. Također, kao povjesničar, uočava dosadašnje borbe i sukobe unutar društva i država, kao i između pojedinih država te procjenjuje da će doći do velikih ratova i sukoba u borbi za dostizanje besmrtnosti.

Ovakva se kataklizmička predviđanja poklapaju u Hararija i Desnice. Obojica vide besmrtnost kao izvor novih, još snažnijih i opasnijih ratova, koji će svojom žestinom i značenjem nadići sve dotadašnje sukobe. U skladu s navedenim, bit će dodatnih socijalnih diferencija s različitim rezultatom, pa u Desnice dovode do stvaranja totalitarnih režima, dok Harari pretpostavlja rat neizvjesnog ishoda jer će umjesto dosadašnje ekonomske doći do biološke nejednakosti. Iščitavajući pesimizam u obojice autora, možemo ga povezati s otuđenjem od prirode. Stvorenom dihotomijom između kulture i prirode, u obama se analiziranim djelima kultura stavlja u superioran odnos. Inicijalna ideja o čovjeku kao besmrtniku, kreatoru i gospodaru (u romanu Homo Deus) u svojoj je zamisli protuprirodna. Polazeći od protuprirodnosti same ideje, njezina realizacija također završava protuprirodnim posljedicama jer oba sustava (totalitarni režimi, ratna zbivanja) impliciraju vrhovne gospodare (ljude, odnosno dijelove političke, vojne i gospodarske elite) nad drugima/Drugima (uključujući ostatak ljudskog roda, ali i sva ostala živa subića te prirodu).

Usporednom analizom ovih dvaju djela dolazimo do analize završetka, odnosno kraja njihovih djela. Obojica ostavljaju mogućnost pozitivnog kraja, tj. odabira pozitivnog puta 
u budućnost. Autori dijele humanistički nazor prema svijetu u koji treba uklopiti znanost i znanstvena dostignuća. Harari vidi odabir pravog puta u zajedničkom globalnom upravljanju umjesto dosadašnjih nacionalnih upravljanja. Desnica podcrtava razum i racionalno rješenje u kombinaciji s empatijom kao ispravan odabir budućnosti. Odabir pozitivnog rješenja i puta koji će spriječiti pesimizam i potonuće u protuprirodnu dekadenciju čovjekove superiornosti i samodostatnosti direktno je povezan s odustajenjem od besmrtnosti kao vrhunca protuprirodnog postupka, kojim se negiraju povezanosti i međusobni suodnosi s prirodom kao cjelinom, koju čini i čovjek zajedno s drugim živim i neživim bićima.

Dosadašnja komparacija Desnice i Hararija svela se na antropocentričan pristup u kojemu je temelj analize bila direktna društvena posljedica (potencijalne) besmrtnosti. Drugim riječima, analizirana je kulturna (civilizacijska) komponenta, dok su okoliš i priroda zanemareni. Međusoban odnos između kulture (civilizacije) i prirode (okoliša) varira u samim definicijama pojedinih ekokritičara. ${ }^{23}$ Neovisno o tome kako tumačimo taj odnos, nedvojbeno je da on postoji. U obama djelima priroda nije jasno ocrtana kao središnji subjekt, već se autori bave društvenim posljedicama besmrtnosti. Bez obzira na to, priroda nije samo objekt nego i bitan čimbenik u ovom međusobnom odnosu. Zato se možemo zapitati koliko je čovjek odlučio izaći iz prirodnog ciklusa (koji čini zajedno sa svim živim bićima, a posljedično i neživim), dokazujući svoju superiornost (odnosno, kako Harari eksplicitno navodi, postajući bogom), manifestiranu težnju k besmrtnosti. Time čovjek (kao i odnosom prema bolestima, gladi i nadvladavanjem prirodnih nepogoda) napušta suodnos $s$ drugim živim bićima postajući superioran izvanjski element. Uspjeh pobjede nad smrću kao nedjeljivim dijelom prirode i ciklusa života kroz koji sva živa bića prolaze donosi čovjekovu pobjedu nad mističnim i nepoznatim, ali istodobno pridonosi napuštanju povezanosti s prirodom. Ovakvo napuštanje odnosa s prirodom, uz istodoban porast tehnoloških dostignuća (Harari i Desnica dovode besmrtnost u vezu s farmaceutskom industrijom, robotikom i tehnologijom), kao posljedicu ima rastakanje postojećih ukorijenjenih društvenih odnosa, ali i stvaranje protuprirodnih (a time i protuljudskih) prožimanja, odnosa i društvenih promjena. U konačnici, stavljanje svega raspoloživog na razvoj, tehnološka i znanstvena dostignuća, kao i porast kapitala dovode do sukoba s prirodom u kojemu čovjek ne može pobijediti, a gubitnici su svi.

Ekološki problemi koje treba analizirati jesu povezanost hrane i okoliša te bolesti, ali i predodžbe o životinjama. Desnica podcrtava da je hrana bila najveći problem koji se manifestirao izumom athanatika jer je Zemlja postala nedostatna za sve veći broj ljudi. ${ }^{24}$ Time besmrtnost prelazi u ozbiljan ekološki problem. Ovime Desnica dovodi u kontrast temeljne potrebe i obilježja živih bića (prehranu, tj. hranjenje kao proces održavanja života i smrtnost/besmrtnost), pokazujući njihov međusoban odnos te svojevrstan paradoks jer ljudi u želji da dostignu zamišljen ideal besmrtnosti, a zanemarujući sve ostale čimbenike prirodnog ciklusa, stvaraju situaciju nedostatka hrane, jedne od osnovnih životnih potreba kao preduvjeta bilo kakvih daljnjih ostvarenja. To je put $\mathrm{k}$ distopiji u kojoj je čovjekov pokušaj

\footnotetext{
23 Primjerice, Greg Gerrard smatra da je izazov ekokriticizma uvijek imati na umu načine na koje je priroda kulturno izgrađena, a s druge strane, da kao činjenica postoji. Usp. Greg Gerrard, Ecocriticism, Abingdon $2004 ., 10$.

24 V. Desnica, Pronalazak Athanatika, 21.
} 
ovladavanja životom i smrću (u vidu besmrtnosti) nužno doveo do uništenja prirode, destrukcije okoliša i dehumanizacije.

Životinje se spominju samo dva puta u Desničinu romanu. Prva životinja koja se spominje jest vuk na samom početku romana, kao jedna od odrednica života u prošlosti:

Ljudske riječi i ljudski strahovi dolaze i izlaze iz mode. Kolik je udio u mislima i osjećanjima negdašnjeg čovjeka imala riječ vuk! Gotovo čitav život bio je „u znaku vuka“! A ko još danas misli na vuka? Kome dandanas pada na um da oboli od likantropije? Danas se čovjek više ne boji smrti... ${ }^{25}$

Drugo je spominjanje usporedba ljudi u vremenu athanatika, koji su se pretvorili u zvijeri:

Rekli smo: ljudi su postali zvijeri. A time su za njih prestale sve stege i obveze, sva moralna i druga načela, obzir, konsideracije, predrasude ili kako god to hoćete da nazovete. Budući zvijeri, nisu više znali ni što je račun, ni oportunost, ni taktika i taktički oprez, ni svrsishodno ekonomisanje snagama, ni mudro čuvanje glave. Srljali su bezumno u propast, ginuli su kao muhe - ali su ginuli. ${ }^{26}$

Navođenje vuka u ovom slučaju upućuje na srednjovjekovne predodžbe o vukodlacima kao strašnim bićima i strahu koji su izazivali u ljudi tijekom prošlosti, što je iščeznulo izumom athanatika. ${ }^{27}$ Radi se o usporedbi ljudskog ponašanja sa zvijeri, odnosno korištenju riječi zvijeri (u izvornom značenju jednog reda kopnenih sisavaca) kao metafore za neuređenu, divlju zajednicu ili gomilu jedinki koje funkcioniraju u distopiji izuma i djelovanja athanatika te stoji u suprotnosti s društvenim normama, odnosima i pravilima ponašanja. Izborom ove riječi, koja ima snažnu simboličnu poruku nečega stranog ljudima, Desnica pokazuje posljedicu nekontroliranog tehnološkog razvoja u vidu pesimizma, rušenja društvenih normi i beznadnosti. Upravo zbog narušavanja prirodne ravnoteže ljudi i drugih subića (jer ljudi dobivaju besmrtnost i time postaju i doslovno i simbolički superiorni), kao odgovor javlja se pesimistična distopija za koju pisac ostavlja mogućnost optimističnog kraja.

Vladan Desnica navodi preslikavanje pojedinih društvenih odnosa na bolesti, među kojima vladaju određena pravila:

Da se ne bi slučajno desilo da pacijent, mjesto od raka umre od infekcije! Jer, u internom saobraćaju među bolestima postoji gentlemen's agreement. Tu nema otimačine ni presizanja. Možda tek izuzetno, neka nova nevaspitana bolest koja još ne pozna pravila igre, zaleti se preko reda sa svojom viljuškom. Ali je odmah klopnu po nadlanici. Tu vlada savršeno poštovanje rezervacija. Tako, na primjer, ako neko ima da umre od raka, sasvim je isključeno da mu, recimo, padne kap. Može da se ljubi u usta s kužnima (empestés), može da znojan skače naglavce u hladnu vodu šesnaest puta dnevno, on neće oboljeti od kuge, on neće dobiti upalu pluća! ${ }^{28}$

25 Isto, 8.

26 Isto, 62. Vrlo sličan citat, gotovo identičan, nalazi se i na str. 72, uz uredničku napomenu o ponavljanju dijela teksta.

27 O vukodlaku, likantropiji u popularnoj kulturi s primjerima iz Hrvatske usp. Ingrid KiršA, Likantropija upopularnoj kulturi, diplomski rad, Sveučilište u Zagrebu, Hrvatski studiji, Odsjek za kroatologiju, 2017.

28

V. Desnica, Pronalazak Athanatika, 15. 
Ideja prezentacije odnosa među bolestima kao preslike društvenih odnosa može se iščitavati kao premreženost i povezivanje prirodnih pojava (što bolesti jesu), živih bića (od čovjeka do različitih mikroba, virusa i bakterija) i društvenih odnosa. Tako imamo premreženost prirode i društva jer se mogu koristiti pojedina društvena znanja i odnosi u primjeni na prirodu i obratno, a to upućuje na jedinstvo živih bića i neživih tvari kao cjelokupnosti koja čini prirodu na Zemlji.

U Hararija je moć sadržana u ljudima izvor opasnosti za cijeli planet, stoga se trebaju zapitati koliko je sprečavanje gladi, ratova i bolesti, uz popratan ekonomski rast, bilo u skladu s potrebama Zemlje. Iz tog razloga autor smatra da treba birati ekološku stabilnost kako bi se izbjegla katastrofa. ${ }^{29}$ Besmrtnost kao neželjenu posljedicu nosi određene ekološke probleme za čovječanstvo, ostala živa su-bića i planet u cijelosti.

\section{KIŠA KAO EKOKRITIČKI FENOMEN}

Priroda (u najširoj definiciji pojma) sa svim raznolikim prirodnim pojavama relativno je česta u književnom stvaralaštvu. Brojni su se književnici koristili prirodnim pojavama poput kiše, sunca, snijega, vjetra da bi pridonijeli atmosferi, simbolički se izrazili o stanju, osjećajima i zbivanjima ili ih na određene načine uključili u radnju svojih djela. Ekokriticizam je u svojoj definiciji povezivanje prirode i književnosti pa su prirodni fenomeni drugačije interpretirani od uobičajene analize simbola ili kulise događaja.

Osim smrti, koja je temeljna nit samog romana Pronalazak Athanatika, za ekokritičko čitanje važna je prirodna pojava - kiša. Jedna je od temeljnih postavki ekokriticizma povezivanje prirode - uključujući i sve prirodne pojave $-s$ književnošću. Kiša se u romanu pojavljuje nekoliko puta. Roman započinje spominjanjem kišnog popodneva tijekom kojega pripovjedač sjedi u kavani s Krezubim. Desnica kroz pripovjedača opisuje kišu koja danima pada ravnomjerno. Promišlja o kiši kao vodi - kako i odakle dolazi, postoji li ciklus ili je to nova voda:

Je li moguće da je to uvijek nova, nerabljena voda - ta odakle bi tolika! - ili one iste, već jednom upotrebljene količine, u zatvorenom krugu, kroz kanale i izljeve otječu u neka podzemna sabirališta, tu se na brzu ruku filtriraju i regeneriraju, pumpama ponovo tjeraju gore, pa odozdo opet toče, cijede, cure... A ako je tako, tad zbilja, izvan nekog nepredviđenog kvara na strojevima, nema izbavljenja!... ${ }^{30}$

Roman završava kišom i njenim ujednačenim padanjem, „kao da je oduvijek kišilo i kao da će dovijeka kišiti“" ${ }^{31}$

Desnica kišu promatra na nekoliko razina: a) na simboličkoj razini, uspoređujući je s tijekom vremena kao konstantu u kojoj se nižu događaji ili se ništa ne događa, no svejedno teče (i kiša i vrijeme); b) na prirodnoj, odnosno tehničkoj razini, promišljajući odakle se stvara i kako slijedi prirodni ciklus kruženja vode u prirodi, pri čemu taj proces zamišlja

\footnotetext{
29 Y. N. Harari, Homo Deus, 23-24.

30 V. Desnica, Pronalazak Athanatika, 7.

31 Isto, 80.
} 
kao niz tehničkih rješenja (sabirališta, pumpe, filteri); c) kao poveznicu između pripovjedača i kiše koja je „tipična kavanska“ i pokazuje poveznicu između početka i kraja romana jer kiša pada cijelo vrijeme tijeka romana.

Važnim se čini zadržati se na tehničkoj razini, odnosno objašnjavanju kiše kao sustava tehničkih rješenja za kruženje vode u prirodi. Osim što daje gradacijski uvod u roman, u kojemu će pokazati vrhunac tehnološke civilizacije koja kreira athanatik, ovakav pristup kiši kao tehničkom rješenju, a ne uobičajenom prirodnom ciklusu, pokazuje kako čovjek budućnosti iz vremena athanatika promatra pojave oko sebe - ne kao prirodne pojave, čime je naglašena negacije prirode.

Prirodne pojave poput kiše relativno su česte u književnosti te nose različitu simboliku. Koristeći se idejom Susan Farrell o povezivanju kiše sa smrću, što ona čini na primjeru čitanja djela Zbogom oružje američkog književnika Ernesta Hemingwayja, Desničina kiša dobiva novo značenje ne samo kao kulisa radnje već i kao pozadina za cijelu priču o odnosu života, smrti i besmrtnosti. Prema mišljenju Susan Farrell, u romanu Zbogom oružje može se primijetiti povezivanje kiše i smrti na temelju primjera strahova od kiše te smrti koja je povezana s njom. ${ }^{32}$ Najbolje je to vidljivo u citatu: „Bojim se kiše jer ponekad vidim sebe mrtvu u njoj - rekla mu je - a ponekad vidim tebe mrtvog u njoj. ${ }^{\text {"33 }}$ Ako primijenimo taj model na roman Pronalazak Athanatika, pojava kiše na početku i kraju romana upućuje na smrt, odnosno smrtnost koja je u pozadini dijaloškog romana i razgovora o besmrtnosti između Krezubog i pripovjedača. Štoviše, Desničine riječi o kiši kao konstanti („kao da je oduvijek kišilo i kao da će dovijeka kišiti“) dodatno potvrđuju tu smrtnost, odnosno prirodni odgovor na čovjekova traganja o besmrtnosti. S druge, pak, strane, Desnica upućuje na problem „kvara i izbavljenja“ od kiše, čime pokazuje da priroda zajedno sa svojom pojavom, kišom, nije samo kulisa i pozadina fabule romana i čovjekova života, nego je aktivan činitelj, ravnopravan čovjeku i konstanta u ljudskom životu, oblikujući ga kao dio prirode u dodiru s prirodnim pojavama (bilo kišom, bilo smrću). U tom bi se kontekstu moglo tumačiti početak i kraj romana u kojemu je opisana kiša.

\section{PRONALAZAK AthanatiKa KaO PRETEČ́a OKOLIŠnih/ EKOLOŠKIH DISTOPIJSKIH ROMANA}

Suvremena hrvatska književnost ne obiluje romanima koji se radnjom vezuju uz distopijsku ${ }^{34}$ budućnost, pri čemu bi ona bila određena okolišnim/ekološkim čimbenicima. Najreprezentativniji su primjeri romani Josipa Mlakića Planet Friedman i Ede Popovića Mjesečev meridijan.

32 Susan Farrell, „Rainy Day Blues: The Role of Weather in A Farewell to Arms“, College of Charleston Blogs (http:// blogs.cofc.edu/hons110/files/2011/10/Rain-in-Hemingway.pdf). Usp. Ernest HemingwaY, A Farewell to Arms, New York 1929.

33 E. Hemingway, A Farewell to Arms, 135. Preveo G. Đ.

34 O samim definicijama pojma i razilaženjima v. Miranda Levanat-Peričić, „Čitanje distopija iz aspekta različitih teorija žanra: Pavličić, Suvin, Frow“, Komparativna povijest hrvatske književnosti. Vrsta ili žanr. Zbornik radova s XIX. međunarodnoga skupa održanog od 29. do 30. rujna 2016. godine u Splitu (ur. Vinka Glunčić-Bužančić i Kristina Grgić), Split - Zagreb 2017., 249-258. 
Radnja romana Planet Friedman događa se na zagađenom planetu u koji se pretvorila Zemlja pobjedom Friedmanove ekonomske doktorine. Ljudi se dijele na nekoliko kategorija, odnosno skupina ili zona: A - privilegirani, B - osobe koje mogu postati privilegirane, C - odbačene osobe. Spomenute su zone strogo odvojene. Središnja je figura Gerharda Schmidta. Iako je pripadnik elite, tijekom romana - zahvaljujući svojoj pacijentici Pauli Bolt, uspješnoj atletičarki i invalidu - dobiva priliku sagledati ostale, deprivirane društvene skupine. U svijetu bez emocija i knjiga, kojim dominira kapitalizam, korporacije (Vijeće dvadeset i pet koorporacija, kompanije poput Rosche i Natto) i reality showovi kao mjerila vrijednosti, i u kojemu je najvažnije biti uspješan, Schmidt zahvaljujući knjigama Shakespearea i Yeatsa - kojih nema u svijetu zone A jer nisu opstale - dobivenih od Paule, otkriva svoju ljudsku dimenziju. Važna je poveznica Gerharda s njegovim ocem Andreasom, koji je pokazao humanost na Friedmanu noseći lijekove i cjepivo bolesnima i potrebitima u nižoj skupini (B) tijekom supergripe te je kažnjen i umoren zbog zločina iz samilosti. Schmidt i Paula upoznaju vođu pobunjenika Blacktootha koji tiska i distribuira knjige, ali poslije i njemu smetaju jer postaje diktator nakon pobjede. Gerhard govori o povijesti kao magnetnom polju s polovima revolucija - kontrarevolucija. Planet Friedman završava odlaskom Gerharda, Brucea, Gerhardova sina i Paule na Ždralove izvore, mjesto na kojem će biti sigurni. ${ }^{35}$

Mlakićev roman obiluje referencama na sadašnji svijet i njegove aktere. Primjerice, najmoćniji čovjek zove se Steven Yobs. Time pokazuje distopijsku budućnost kao uvijenu sadašnjost. Također, roman obuhvaća globalnu sliku u sklopu koje smo i mi. ${ }^{36}$

Edo Popović napisao je roman Mjesečev meridijan, u početku prateći Mirka Grafa, pripadnika zajednice Korov, koja organski uzgaja poljoprivredne proizvode. Graf putuje u Zagreb, prikazan kao distopijski grad pun marginalnih društvenih skupina - beskućnika, nezaposlenih, prosjaka. Susreće poznanika Josipa Pavlovića, nezaposlenog nekadašnjeg djelatnika SalarLaba. U romanu su ljudi podijeljeni na dvije skupine, sukladno s odnosom prema okolišu: Otrovani - koji su uništili okoliš - te Zaboravljeni - koji žive u središnjoj Europi u svojevrsnoj oazi nezagađenog okoliša, piju vodu iz potoka, hrane se divljim plodovima i životinjama. Glavni su likovi djevojka Mila Salar - kći vlasnika SalarLaba i bogataša Zorana Salara, voditeljica projekta o Zaboravljenima, skupini odabranih muškaraca i žena koji će na izoliranoj lokaciji živjeti kao prapovijesni lovci i sakupljači - i mladić Kaj - jedan od Zaboravljenih, čiji je otac Jakov bio zadužen za stvaranje priča o povijesti i životu Zaboravljenih. Roman završava Mirkovim pripovijedanjem o Japodskoj dolini, mjestu komune gdje žive Mila, Josip, Kaj i drugi. ${ }^{37}$ Popovićev roman također ima brojne reference na sadašnjost jer uključuje i zbivanja s kojima smo se sretali ili čuli za njih uz određene zamišljene ili izmišljene događaje. ${ }^{38}$

\footnotetext{
35 Josip Mlakić, Planet Friedman, Zagreb 2012.

36 Strahimir Primorac, „Imamo li komu slati poruke u boci?“, Vijenac, 21/2013., br. 495 (http://www.matica.hr/vijenac/495/imamo-li-komu-slati-poruke-u-boci-21432/).

37 Edo Popović, Mjesečev meridijan, Zagreb 2015.

38 Strahimir Primorac, „Potraga za svijetom slobode“, Vijenac, 23/2015., br. 561-562. (http://www.matica.hr/vijenac/561\%20-\%20562/Potraga\%20za\%20svijetom\%20slobode/).
} 
Pronalazak Athanatika kao značajno stariji prethodnik te Mjesečev meridijan i Planet Friedman mogu se komparativno promatrati u nekoliko slojeva. Usporedbom ovih triju djela mogu se uočiti određene sličnosti u samom uzroku promjena, što je prvenstveno ekologija i zaštita prirode, odnosno izostanak brige o okolišu (zagađenje, uništen okolišs, smrt - besmrtnost). Autori stvaraju uzročno-posljedični niz jer ekološke promjene, kao uzrok, dovode do značajnih posljedica u vidu socijalnih promjena manifestiranih u čvrsto podijeljenom društvu na dvije (Desnica, Popović) ili tri skupine (Mlakić). Konačna je posljedica stvaranje totalitarnog svijeta, bilo diktature s referencama na nacističko-fašističku (Desnica), bilo beskrupuloznog korporativno-kapitalističkog svijeta (Mlakić, Popović). Projekcija ekološki onečišćene budućnosti i čovječanstva koje se kreće k ponoru uvjetovana je neprijateljima tadašnjosti (sadašnjosti) pa su zato strahovi Vladana Desnice usmjereni na mogući povratak nacizma i fašizma, s tada još uvijek svježim uspomenama, dok su suvremeni pisci Popović $i$ Mlakić usmjereni na negativnosti veoma aktualnog korporativnog i kapitalističkog svijeta. Gradacijski postavljeno, Mlakićevo je društvo poveznica između Desničina i Popovićeva društva jer u roman, osim korporativnog kapitalizma, uvodi i diktaturu u kojoj se kontrolira znanje, emocije i cjelokupnost života osmišljenu od Tvorca, Friedmana. ${ }^{39}$ Ovime Mlakić pokazuje vrhunac korporativnog kapitalizma, koji nužno odlazi u diktaturu, odnosno totalitarizam kao svoj temeljni cilj.

Sva trojica autora pokazuju nedjeljivost čovjeka od prirode te posljedice takve podjele. Izostanak veza s prirodom i razaranja suodnosa s njom - postavljajući kulturu, civilizaciju i razvoj kao superiorne - dovode do ekoloških problema koji se nužno reflektiraju na društvene probleme. Iz toga može se izvući veoma pesimističan pogled na takvu budućnost koja je distopijska - uništena, dehumanizirana, neprirodna i antiprirodna, čime ni ljudi nemaju budućnost te protuprirodnim ponašanjem uništavaju i onu vlastitu.

U drugom sloju možemo analizirati vrijeme i mjesto samih radnji. Desnica i Mlakić stvaraju puno neodređeniji svijet, ispuštajući točnu godinu, odnosno godine radnje, kao i detaljnije opise prostora, tj. teritorija u kojemu se ona odvija, pri čemu su ti teritoriji i prostori zapravo svjetski, globalni i mogu se vezati uz različite zemlje. Popović je puno određeniji opisom prostora (Zagreb, Japodska dolina, Hrvatska, srednja Europa), a vremenski radnju smješta u neodređenu, ali blisku budućnost.

Tematski ciklus besmrtnost - smrt - život postaje zajednička točka svoj trojici autora. Desnica je cijeli svoj roman osmislio oko teme besmrtnosti i pronađenog athanatika, a Popović se u rubnom dijelu svog romana također dotiče besmrtnosti, pri čemu je najilustrativniji dio o povezanosti besmrtnosti i novca (kapitala), odnosno zamjene dotrajalih organa. Time se Popović približava Hararijevu doživljaju besmrtnosti. Mlakić prikazuje smrt uz odsutnost bilo kakvih emocija i empatije. Sve se promatra kroz uspjeh, korist i vlastiti probitak uz pohlepu. U Popovića i Mlakića može se govoriti o smrtnosti, odnosno o smrti planeta Zemlje slijedom dugotrajnih onečišćenja i ekoloških problema. Desnica naslućuje takav ekološki problem uočavanjem nestašice hrane nakon izuma athanatika. Sva trojica autora dovode u međusoban odnos besmrtnost pojedinca sa smrtnošću prirode, što dugoročno dovodi i do smrtnosti ljudskog roda.

39 Tea Šitum, „Planet Friedman“, Citajme.com (http://citajme.com/planet-friedman/). 
Djela možemo analizirati na temelju predodžbi binarnog para sloboda - dominacija. Zajedničko je svim autorima stvaranje svijeta dominacije i moći u kojoj povlašteni (ako ih zamislimo kao jednu skupinu) dominiraju nad svima drugima, pri čemu se humanizam kao odrednica potpuno gubi u takvoj budućnosti koja je izgrađena - možda je bolji termin razgrađena - na ekološkim problemima. Zato je sloboda najvǎniji termin u koji se mogu svrstati analizirana Desničina, Mlakićeva i Popovićeva djela. Matko Vladanović navodi za Popovićev roman: „U moru lažnih informacija, nametnutih i iskonstruiranih identiteta, manipulacija i propagande odgovor na pitanje slobode različit je za svakog pojedinca. ${ }^{40} \mathrm{Te}$ riječi odlično opisuju pojam slobode u ovim djelima, neovisno o pojedinim zajedničkim karakteristikama pojedinih likova. Pitanje dominacije i superiornosti kao dijela binarnog para u odnosu sa slobodom u nedjeljivoj je vezi s prirodom i uništenim okolišem. U svim trima djelima dominacija čovjeka (kao koorporativnog, racionalnog tehnološkog bića) u kontrastu je sa slobodom drugih živih subića, ali i sa slobodom čovjeka (pojedinca koji ima i onu drugu stranu emocija i empatija, čineći dio prirodne ravnoteže i ciklusa života).

Tragom analizirane slobode i dominacije, postavlja se pitanje autorovih projekcija budućnosti i samog završetka romana. U završetku svojih djela Desnica i Mlakić nude optimizam: u Desnice riječ je o završnom uništenju athanatika, a Mlakić otvara neiskvaren svijet (Ždralove izvore) kao mjesto novog početka, iako uz dozu skepse (otvoreno pitanje o porukama u boci). ${ }^{41}$ Popovićev kraj nosi optimisitičke natruhe jer omogućuje različite predodžbe slobode definirane prema željama pojedinog lika (putovanja Kaja i Josipa, Mirkova promišljanja o budućnosti i mjestima na koja možemo ići i gdje možemo ostati). ${ }^{42}$ Zajednička je karakteristika završetka ovih romana ta da je optimizam u svojevrsnom povratku prirodi - u Desnice u uništavanju protuprirodnog athanatika koji narušava prirodnu ravnotežu, u Mlakića u odlasku u zaštićeno područje, odnosno mjesto gdje nije uništena priroda, a u Popovića vrlo slično, u putovanju za slobodom i mjestima u kojima postoji neuništena priroda.

Koristeći se metodološkim obrascem Louise Squire iz rada „Death and the Anthropocene: Cormac McCarthy's World of Unliving", u kojemu se referira na ideje Paula Crutzena o antropocenu, geološkom razdoblju u kojemu je dominantan utjecaj čovjeka na geološke i okolišne promjene, te Jacquesa Derride o smrti, ona navedene ideje (antropocen i smrt) stavlja u kontekst književne teorije i analize književnog djela. Autorica analizira književno djelo Cormaca McCarthyja koristeći se doživljajem smrti Jacquesa Derride koji smatra sljedeće: „Naučiti živjeti znači naučiti umrijeti, naučiti sve staviti pod isti račun, odnosno prihvatiti apsolutnu smrtnost (bez spasenja, uskrsnuća i iskupljenja ni za sebe ni za druge) (...) filozofirati znači naučiti umrijeti. “43 Nadalje, Squire promišlja koliko su dva Derridina koncepta o smrti i arhivi primjenjiva na književna djela: „a) nemogućnost otkrivanja granice smrti kao takve i b) promišljanje o krajevima kojima dekonstrukcija postaje odgovorna za

\footnotetext{
40 Matko Vladanović, „Edo Popović: Mjesečev meridijan“, Moderna vremena (http://www.mvinfo.hr/clanak/edo-popovic-mjesecev-meridijan).

41 J. Mlakić, Planet Friedman, 253.

42 E. Popović, Mjesečev meridijan, 171

43 Citirano prema Louise SQuire, „Death and the Anthropocene: Cormac McCarthy's World of Unliving“, The Oxford Literary Review, 34/2012., br. 12, 215. Preveo G. Đ.
} 
budućnost izvan iskustva, pri čemu tada antropocen može biti vrijeme u kojemu se bojimo onečišćenja arhive fizičkim događajima pa zato dekonstruiramo (iako težimo rekonstruirati) tko smo “. ${ }^{44}$ Pita se i mogu li se povezati smrt i antropocen kao dva koncepta te može li se koncept Derridinih arhiva kao matrica iščitati u odabranim književnim djelima (što ona čini u djelima Cormaca McCarthyja). Povezivanje ekokritike i dekonstrukcije otvoreno je pitanje u suvremenoj metodologiji ekokritike i stvaranju suodnosa s postmodernizmom. Bez obzira na zajedničke korijene u poststrukturalističkim analizama, postmodernizam i ekokritika razdvajaju se u dijelu oko dekonstrukcije. O ovom problemu Domagoj Brozović navodi sljedeće:

Ono što ekokriticizam razlikuje od glavne struje poststrukturalizma je razvijanje zrelog protustava postmodernističkoj inklinaciji neobuzdane simboličke, jezične i kulturalne igre pri čemu se zagovara rekonstruktivni pristup jeziku s čvrstim osloncem na superstrukturu prirode. Iza naizgled glavnog ekokritičkog problema veze okoliša i diskursa razvija se aksiom o ekstratekstualnoj i ekstradiskurzivnoj prirodi koji otvoreno problematizira dekonstrukcijsko brisanje relacije $s$ realnim referentima, što ima potenciju da rezultirala ozbiljnim epistemološkim konzekvencama za suvremenu književnu i kulturnu teoriju i poticajem za rekonstrukciju pojma poetičke reprezentacije koju postmodernizam tretira apriorno neadekvatnom. Ekokritički izazov postmodernizmu i ključno pitanje postaje kako diskurzivnost i materijalnost ponovno dovesti u vezu. ${ }^{45}$

Mišljenje Domagoja Brozovića i autora na koje se poziva jedno je od mogućih interpretacija odnosa postmoderne i ekokritike. ${ }^{46}$ Citirajući Timothyja Morgana, koji smatra da je dekonstrukcija tajni prijatelj ekokritike, ${ }^{47}$ smatram da se može napraviti zajednička poveznica između ekokritike i postmodernizma.

Ideje Louise Squire o povezivanju smrti i Derridinih arhiva možemo primijeniti na ekokritičko čitanje odabranih djela Desnice, Mlakića i Popovića. Ekološka je katastrofa neizbježna posljedica djelovanja čovjeka u antropocenu te će ponašanja u sadašnjosti i budućnosti povećati takvu situaciju. Koliko se isplati živjeti u svjetovima Pronalaska Athanatika, Planeta Friedman i Mjesečeva meridijana? U svjetovima različitih tipova terora, kontrole i praćenja u kojima su vrlo jasne i naglašene podjele ljudi? Derridina ideja arhiva može se iščitati u ovim romanima, posebno u Mlakića i Popovića, gdje većina likova nema nikakvog doticaja s prošlošću. Iznimke su likovi anarhista i njihova vođe, poslije Schmidt i Paula u Mlakića, Zaboravljeni te Mila i Mirko u Popovića, koji omogućuju izlazak iz zagađenog svijeta i planeta sjećanjem na prošlost i očuvanjem pojedinih vrijednosti iz prošlosti poput knjiga, čitanja, emocija u Mlakića ili života u skladu s prirodom u Popovića. U Desnice najbliži su tome „posmatrači“, kao kolektivan naziv za ljude „koji nadživljuju historiju i prate njen pogreb “ ${ }^{48}$ te pripadnici hereze koji su htjeli spoznati istinu. Upravo su poveznice $s$

44 Isto, 218. Preveo G. Đ.

45 D. Brozović, „Čitati zeleno“, 31.

46 Za različita mišljenja o odnosu postmoderne i ekokritike usp. Serpil OpPermann, „Theorizing Ecocriticism: Toward a Postmodern Ecocritical Practice“, Interdisciplinary Studies in Literature and Environment, 13/2006., br. 2, $103-128$.

47 Timothy Morton, „Deconstruction and / as Ecology“, The Oxford Handbook of Ecocriticism (ur. Greg Garrard), Oxford 2014., 291-304.

48 V. Desnica, Pronalazak Athanatika, 64. 
prošlošću otvorile mogućnost za promjenu i optimizam. Mišljenja sam da je prekid odnosa s prirodom nužno doveo do prekida odnosa s prošlošću i tradicijom. Taj se odnos reflektira u pesimizmu koji nas čeka u distopijskoj budućnosti. Izvorište za optimizam leži u ponovno povezivanju s prirodom i obnovom odnosa prema prošlosti. Ljudske emocije, empatija, hrabrost pojedinca, nada i racionalan pristup omogućili su tragove boljeg života u budućnosti.

\section{ZAKLJUČNA RAZMATRANJA}

Ekokritičko čitanje romana Pronalazak Athanatika pokazuje dvije prirodne pojave koje se provlače kroz roman. Prva je ideja smrti i besmrtnosti, koja je temeljni motiv romana i središnja os fabule. Uspoređujući i povezujućín ${ }^{49}$ djela Vladana Desnice i Yuvala Noaha Hararija, može se zamijetiti da obojica, analizirajući potencijale besmrtnosti, vide niz problema koje ona otvara, počevši od ekoloških problema, preko društvenih i ekonomskih, do političkih promjena. Bez obzira na različitosti u dolasku do besmrtnosti - Desničin izum lijeka i Hararijeva tehnička rješenja - obojica dolaze do sličnih zaključaka, pri čemu je besmrtnost uvjetovana znanstvenim istraživanjima $i$ ima široke posljedice u vidu društvenih promjena koje dovode do trajnih i opasnih sukoba. Ovi sukobi svoje izvorište imaju u pokušajima čovjekove supremacije nad prirodom i ostalim živim subićima, bazirajući se isključivo na tehnološkoj dimenziji te tzv. razvoju i napretku. Priroda postaje objekt čovjekova puta k nadmoći, što se prikazuje pokušajima besmrtnosti i pronalaženja rješenja za nj kao vrhunca tehnološko-znanstvenog uspjeha. Iz toga proizašla čovjekova samodostatnost dovodi nužno do egzistencijalne, a potom i društvene krize u kojemu taj isti čovjek postaje gubitnik, pokušavajući zavladati prirodom, a istodobno se izdvajući iz nje.

Druga ekokritička analizirana pojava jest prirodna pojava kiše. Smatram da je Desnica prikazom kiše na početku i kraju romana dao kontrast razgovoru pripovjedača i Krezubog, koji raspravljaju o besmrtnosti jer bi kiša, ako je tumačimo sukladno s čitanjima Hemingwayja, označavala smrt, odnosno, u ovom slučaju, smrtnost ljudi. Kiša je prikazana i kao tehnički problem, a ne prirodna pojava, čime čovjek iz vremena athanatika odbacuje prirodne pojave i svijet oko sebe tumači isključivo tehnološkim procesima. Tako je dodatno naglašen odmak od čovjeka i prirode. Odabirom početka i kraja spominjanjem kiše, bez obzira na radnju o besmrtnosti, pisac posredno upozorava na stalnu smrtnost čovjeka, ali pokazuje i prirodu kao aktivnog činitelja, a ne samo kulisu u pozadini čovjekovu djelovanju.

Otvoreno je pitanje koliko se Pronalazak Athanatika uklapa u žanrovska obilježja spekulativne fikcije prema analizi Mirande Levanat Peričić, koja navodi:

Alternativni svijet u ovim je romanima dvostruko udaljen od autorove empirijske zbilje - vremenom budućnosti i nacionalno neoznačenim kulturnim prostorom. Stoga se metažanrovska obilježenost distopije u hrvatskoj književnosti ogleda i u tome što hrvatski roman projicira povijest budućnosti u drugu književnu tradiciju, najčešće onu kojoj distopija izvorno pripada. ${ }^{50}$

$\overline{49}$ O mogućnosti uspoređivanja i povezivanja u povijesnoj znanosti v. Diego Olstein, Thinking History Globally, New York 2015., 59-98.

50 Miranda Levanat-Peričić, „Metažanrovska obilježenost spekulativne fikcije u hrvatskoj književnosti: od Šufflaya do Mlakića“, Komparativna povijest hrvatske književnosti. Fantastika: problem zbilje. Zbornik radova sa XVIII. međunarodnoga 
Smatram da je Pronalazak Athanatika žanrovski blizak spekulativnoj fikciji. Nedefiniranje prostora događanja i samog vremena pokazuju odrednice ove teorije. Time se ovaj roman može uklopiti u niz sličnih romana poput Planeta Friedmana i Mjesečeva meridijana. Osim zajedničkog okolišnog uzroka problema, vidljiva je društvena podjela na povlaštene - neovisno o tome jesu li to besmrtni, oni koji imaju društvenu moć ili ekonomski moćnici - i sve ostale. Ekološki uzrok problema kao posljedicu nosi društvene promjene te sve veće i jasnije socijalne diferencijacije koja završavaju totalitarnim sustavima - fašizmom, nacizmom i korporativnim kapitalizmom u svojim inačicama.

Zanimljiva je Desničina ideja besmrtnosti ljudi u usporedbi sa smrću planeta Zemlje, uočljiva u Popovića i Mlakića. Može li se ove dvije tvrdnje dovesti u vezu? Koji je maksimalan broj ljudi koji istovremeno može živjeti na Zemlji? ${ }^{31}$ Kakav će biti ekološki otisak koji će ostaviti? $?^{52}$ Koliko će ljudsko djelovanje i težnja za moći, uključujući i besmrtnost, pridonijeti odumiranju planeta Zemlje? Kakve će biti društvene posljedice ekoloških promjena kojima smo svjedoci (globalno zatopljenje, otapanje ledenjaka, širenje pustinja, razorne oluje, ratovi za energiju i vodu, zagađenje zraka, vode i tla, iskorištavanje prirodnih resursa i slično)? Ova pitanja samo su poticaj za promišljanja i daljnje radove, posebice u kontekstu umjetne inteligencije, bioinženjeringa i potencijalne besmrtnosti ili nesmrtnosti u budućnosti.

Važnost nedovršenog romana Pronalazak Athanatika ogleda se u poveznici s vrlo aktualnim temama života i smrti kao odnosa prema prevladavanju smrti besmrtnošću, zatim načinom promišljanja potonje, što je veoma važno za dovođenje u vezu s Hararijem, ali i suvremenim izazovima smrti i njezina izbjegavanja. Desnica se može smatrati prethodnikom koji korelira s aktualnim znanstvenim promišljanjima (Harari) i književnim djelima (Mlakić, Popović), upozoravajući kako ekologija i ekološki čimbenici (besmrtnost i porast stanovnika, nedostatak hrane) mogu imati ozbiljne utjecaje na društvene promjene, raspodjelu moći i oblikovanje budućnosti. Time je od književnog djela, određenog kao spekulativna fikcija, Desničin Pronalazak Athanatika postao putokaz za doglednu budućnost i izazove koje nosi. Promišljanja o odabirima i humanistički pogled koraci su k boljoj i ugodnijoj budućnosti za cjelokupno čovječanstvo, živi svijet i planet Zemlju, što bi se moglo nazvati zajedničkim zaključkom Vladana Desnice, Yuvala Hararija, Josipa Mlakića i Ede Popovića išcitanim iz njihovih analiziranih djela.

znanstvenog skupa održanog od 24. do 25. rujna 2015. godine u Splitu (ur. Cvijeta Pavlović, Vinka Glunčić-Bužančić i Andrea Meyer-Fraatz), Split - Zagreb 2016., 316.

51 Prema istraživanjima UN-a, očekuje se značajan rast do 11,2 milijarde ljudi do 2100. godine Usp. World Population Prospects. The 2015 Revision. Key Findings and Advanced Tables, New York 2015., 2 (https://esa.un.org/unpd/wpp/ Publications/Files/Key_Findings_WPP_2015.pdf).

52 Usp. Dražen ŠımlešA, Ekološki otisak. Kako je razvoj zgazio održivost, Zagreb 2010. 


\section{$\cos$}

\section{Literatura}

Peter Berry, Beginning Theory. An Introduction to Literary and Cultural Theory, Manchester - New York 2009.

Thomas Borstelmann, The 1970s. A New Global History from Civil Rights to Economic Inequality, Princeton 2015.

Domagoj Brozović, „Čitati zeleno. Ekokriticizam - neprepoznata mogućnost suvremene hrvatske znanosti o književnosti“, Književna smotra, 44/2012., br. 164-165, 29-35.

Reginald Campbell Thompson, The Epic of Gilgamesh: Complete Academic Translation. Translated from cuneiform tablets in the British Museum literally into English hexameters, London 2007.

Wu Cheng'en, A journey to the West, Beijing 1955.

Jacques Choron, „Death and Immortality“, Dictionary of the History of Ideas (ur. Philip P. Wiener), sv. 1, New York 1974., 635-646 (https://web.archive.org/web/20070311081839/http://etext.lib. virginia.edu/cgi-local/DHI/dhi.cgi?id=dv1-76).

Vladan Desnica, Pronalazak Athanatika, Zagreb 2006.

Goran ĐurĐević, „Yuval Noah Harari, Homo Deus: kratka povijest sutrašnjice“, Ekonomska i ekohistorija, 13/2017., 177-178.

Goran ĐurĐević, „Yuval Noah Harari, Sapiens: kratka povijest čovječanstva, Fokus, Zagreb 2015, 479 str.", Historijski zbornik, 68/2015., br. 1, 203-205.

Simon C. Esток, „Teorija s ruba: životinje, ekokritika, Shakespeare“, Kazalište, 11/2008., br. 3536, 84-97.

Susan Farrell, „Rainy Day Blues: The Role of Weather in A Farewell to Arms“, College of Charleston Blogs (http://blogs.cofc.edu/hons110/files/2011/10/Rain-in-Hemingway.pdf).

Niall Ferguson i dr. (ur.), The Shock of the Global. The 1970s in Perspective, Harvard 2011.

Greg Gerrard, Ecocriticism, Abingdon 2004.

Derek Gladwin, „Ecocriticism“, Oxford Bibliographies (http://www.oxfordbibliographies.com/ view/document/obo-9780190221911/obo-9780190221911-0014.xml).

Cheryll Glotfelty, „Introduction: Literary Studies in an Age of Environmental Crisis“, Ecocriticism Reader. Landmarks in Literary Ecology (ur. Cheryll Glotfelty i Harold Fromm), Athens, Georgia 1996., XV-XXXVII.

Yuval Noah Harari, Homo Deus. Kratka povijest sutrašnjice, Zagreb 2017.

Yuval Noah Harari, Sapiens. Kratka povijest čovječanstva, Zagreb 2015.

Ernest Hemingway, A Farewell to Arms, New York 1929.

William HoRwath, „Some Principles of Ecocriticism“, Ecocriticism Reader. Landmarks in Literary Ecology (ur. Cheryll Glotfelty i Harold Fromm), Athens, Georgia 1996., 69-91.

Ingrid KıršA, Likantropija u popularnoj kulturi, diplomski rad, Sveučilište u Zagrebu, Hrvatski studiji, Odsjek za kroatologiju, 2017.

Karl Kroeber, „Home at Grasmere’: Ecological Holiness“, Publications of the Modern Language Association of America, 89/1974., br. 1, 132-141.

Miranda Levanat-PeričIć, „Čitanje distopija iz aspekta različitih teorija žanra: Pavličić, Suvin, Frow", Komparativna povijest hrvatske književnosti. Vrsta ili žanr. Zbornik radova s XIX. međunarodnoga skupa održanog od 29. do 30. rujna 2016. godine u Splitu (ur. Vinka Glunčić-Bužančić i Kristina Grgić), Split - Zagreb 2017., 249-258. 
Miranda Levanat-Peričić, „Metažanrovska obilježenost spekulativne fikcije u hrvatskoj književnosti: od Šufflaya do Mlakića“, Komparativna povijest hrvatske književnosti. Fantastika: problem zbilje. Zbornik radova sa XVIII. međunarodnoga znanstvenog skupa održanog od 24. do 25. rujna 2015. godine u Splitu (ur. Cvijeta Pavlović, Vinka Glunčić-Bužančić i Andrea Meyer-Fraatz), Split - Zagreb 2016., 307-318.

Suzana Marjanić, „Književni svjetovi s etnološkom, ekološkom i animalističkom nišom“, Narodna umjetnost, 43/2006., br. 2, 163-186.

Suzana Marjanić, „Zoosfera Tita Andronika: ljudska, previše ljudska bestijalnost“, Treća, 10/2008., br. 2, 59-82.

Josip Mlakić, Planet Friedman, Zagreb 2012.

Timothy Morton, „Deconstruction and / as Ecology“, The Oxford Handbook of Ecocriticism (ur. Greg Garrard), Oxford 2014., 291-304.

Krešimir Nemec, „Pronalazak Athanatika - između utopije i distopije“, u: Vladan Desnica, Pronalazak Athanatika, Zagreb 2006., 81-94.

Diego Olstein, Thinking History Globally, New York 2015.

Serpil Oppermann, „Theorizing Ecocriticism: Toward a Postmodern Ecocritical Practice“, Interdisciplinary Studies in Literature and Environment, 13/2006., br. 2, 103-128.

Edo Popović, Mjesečev meridijan, Zagreb 2015.

Strahimir Primorac, „Imamo li komu slati poruke u boci?“, Vijenac, 21/2013., br. 495 (http:// www.matica.hr/vijenac/495/imamo-li-komu-slati-poruke-u-boci-21432/).

Strahimir Primorac, „Potraga za svijetom slobode“, Vijenac, 23/2015., br. 561-562 (http://www. matica.hr/vijenac/561\%20-\%20562/Potraga\%20za\%20svijetom\%20slobode/).

Tizian Raspor, „Yuval Noah Harari, Homo Deus. Kratka povijest sutrašnjice, prevela s engleskog Marija Perišić, Fokus komunikacije, Zagreb 2017, 461 str.", Historiografija.hr (http://www.historiografija.hr/?p=5663).

William Rueckert, „Literature and Ecology: An Experiment in Ecocriticism“, Ecocriticism Reader. Landmarks in Literary Ecology (ur. Cheryll Glotfelty i Harold Fromm), Athens, Georgia 1996., $105-123$.

„Sisyphus“, Encyclopaedia Britannica (https://www.britannica.com/topic/Sisyphus).

Louise SQuire, „Death and the Anthropocene: Cormac McCarthy's World of Unliving“, The Oxford Literary Review, 34/2012., br. 12, 211-228.

Dražen ŠIMLEŠA, Ekološki otisak. Kako je razvoj zgazio održivost, Zagreb 2010.

Tea Šitum, „Planet Friedman“, Citajme.com (http://citajme.com/planet-friedman/).

Tjaša TRČEK, Ekokritika - upodobitve narave v izbranih mladinskih delih, diplomski rad, Univerza v Ljubljani, Pedagoška fakulteta, 2016.

Matko Vladanović, „Edo Popović: Mjesečev meridijan“, Moderna vremena (http://www.mvinfo. $\mathrm{hr} /$ clanak/edo-popovic-mjesecev-meridijan).

World Population Prospects. The 2015 Revision. Key Findings and Advanced Tables, New York 2015. (https://esa.un.org/unpd/wpp/Publications/Files/Key_Findings_WPP_2015.pdf).

„Zagrobni život“, Hrvatska enciklopedija (http://www.enciklopedija.hr/natuknica.aspx?id=66705). 


\section{$\cos$}

\section{An ECOCRITICAL READING OF VLADAN DESNiCA'S NOVEL PRONALAZAK ATHANATIKA}

The author approaches Vladan Desnica's short unfinished novel Pronalazak Athanatika (The Discovery of Athanatic) from an ecocritical perspective. The paper consists of three parts: an ecocritical interpretation of the thematic cycle of death, life and immortality in connection and comparison to Yuval Noah Harari's Homo Deus, followed by an ecocritical analysis of the rain that draws on the the ideas of Susan Farrell, and finally, an analysis of Desnica's novel viewed in the context of other dystopian ecological/environmental novels in contemporary Croatian literature: Josip Mlakić's Planet Friedman and Edo Popovićs Mjesečev meridijan (The Moon Meridian), with a comparison to the ecocritical readings of Louise Squire. The author concludes that Desnica's novel, which he places into the genre of speculative fiction, is a precursor to contemporary scholarly analyses (Harari) and fiction (Mlakić, Popović), cautioning that ecology and ecological factors - immortality, population growth, food shortages and the eventual destruction of the planet - can have devastating consequences for social changes, the division of power and the future that is being created.

Key words: ecocriticism, Pronalazak Athanatika (The Discovery of Athanatic), Vladan Desnica, immortality, Yuval Noah Harari, Josip Mlakić, Edo Popović, cultural studies 